\title{
ANALISIS POSITIVE DEVIANCE: POLA MAKAN YANG MEMPENGARUHI KEJADIAN ANEMIA PADA IBU HAMIL DI KOTA YOGYAKARTA
}

\author{
Ika Mustika Dewi ${ }^{1}$, Prastiwi Putri Basuki ${ }^{2}$, Siti Uswatun Chasanah ${ }^{3}$, Andri Purwandari ${ }^{4}$ \\ ${ }^{1}$ Prodi Keperawatan (S1) dan Ners, STIKES Wira Husada Yogyakarta \\ email: ika_chan45@yahoo.co.id \\ ${ }^{2}$ Prodi Kesehatan Masyarakat (S1), STIKES Wira Husada Yogyakarta \\ email: tiwibasuki19@gmail.com \\ ${ }^{3}$ Prodi Kesehatan Masyarakat (S1), STIKES Wira Husada Yogyakarta \\ email: uswcha.pit@gmail.com \\ ${ }^{4}$ Prodi Keperawatan (D3), STIKES Wira Husada Yogyakarta \\ email: izzah.pd962@gmail.com
}

\begin{abstract}
Introduction: Anemia is a public health problem associated with an increased of morbidity and mortality. Poor eating habits during pregnancy will cause the body's need for nutrients both micro and macro is not met, so will result in malnutrition and anemia. Methods: It was observational study using a cross sectional design. Sampling was done by purposive sampling methods. This dietary data accumulation was done by using Food Frequency Questionnaire. In-depth interviews was used to explore positive eating habit in pregnant women that are not anemic. Hemoglobin was detected by using HemoCue analyzer. Statistical analysis of data was used the Chi Square test. Results: The results show that $88.2 \%$ of the pregnant women are not anemic, $64.5 \%$ of pregnant women often consume enhancers, and $57.9 \%$ of pregnant women rarely consume inhibitors. There was no correlation between consumption of enhancer with anemia $(p=0.478)$. There was no correlation between consumption of inhibitors with anemia $(p=1,000)$. Positive eating habits of pregnant women who are not anemic is often consume foods high in vitamin $C$ and animal protein. Conclusion: There was no correlation between consumption of enhancher and inhibitor with anemia incidence among pregnant women
\end{abstract}

Keywords: Anemia, pregnant women, positive eating habit.

\section{PENDAHULUAN}

Anemia merupakan suatu keadaan ketika jumlah sel darah merah atau konsentrasi pengangkut oksigen dalam darah $(\mathrm{Hb})$ kurang dari normal sehingga tidak mencukupi untuk kebutuhan fisiologis tubuh (Adriani, 2014). Anemia merupakan masalah kesehatan masyarakat yang berhubungan meningkatkan risiko kesakitan dan kematian (McLean et al., 2007). Anemia berhubungan dengan malnutrisi yang merupakan dampak multifaktor dan interaksi antara konsumsi makanan serta kejadian infeksi (Jackson, 2007). Risiko anemia bervariasi sepanjang hidup, tetapi ada beberapa periode rentan yang lebih besar dalam kehidupan. Variasi tersebut karena perubahan cadangan zat besi, tingkat konsumsi zat besi, kebutuhan untuk pertumbuhan atau karena kehilangan zat besi. Anak balita, remaja dan ibu hamil merupakan kelompok rentan anemia (Darnton-Hill et al., 2007).

Pola makan yang kurang baik saat kehamilan akan menyebabkan asupan protein dan vitamin tidak sesuai dengan kebutuhan, metabolisme tidak seimbang sehingga pembentukan $\mathrm{Hb}$ terhambat dan kebutuhan tubuh akan zat gizi baik mikro maupun makro tidak terpenuhi, sehingga akan berakibat pada munculnya berbagai masalah gizi dan anemia baik ringan, sedang maupun berat saat kehamilan (Soetjiningsih, 2007)

Bentuk besi di dalam makanan berpengaruh terhadap penyerapannya. Vitamin $\mathrm{C}$ sebgaai zat enhancher sangat membantu penyerapan besi-nonheme dengan merubah bentuk feri menjadi bentuk fero. Vitamin $\mathrm{C}$ membentuk gugus besi-askorbat yang tetap larut pada $\mathrm{pH}$ lebih tinggi dalam duodenum, mkaa sangat dianjurkan makan makanan sumber vitamin $C$ setiap kali makan. 
Zat yang dapat menghambat penyerapan besi (inhibitor)adalah tanin yang merupakan polifenol yang terdapat di dalam teh dan kopi. Jika besi tubuh tidak terlalu tinggi, sebaiknya tidak minum teh atau kopi waktu makan (Almatsier, 2013)

Anemia sangat terkait erat dengan masalah kesehatan reproduksi (terutama perempuan). Jika perempuan mengalami anemia, maka akan menjadi sangat berbahaya pada waktu dia hamil dan melahirkan. Perempuan yang menderita anemia berpotensi melahirkan bayi dengan berat badan lahir rendah. Selain itu, anemia dapat menyebabkan kematian baik ibu maupun bayi pada proses persalinan (Adriani, 2014).

Data dari Profil Kesehatan Provinsi Daerah Istimewa Yogyakarta (DIY) menunjukkan Prevalensi anemia ibu hamil di DIY mengalami penurunan sejak tahun 2009, prevalensi anemia ibu hamil di DIY tahun $2015(14,85 \%)$ sudah memenuhi target Renstra DIY (56\%). Meskipun begitu, peningkatan prevalensi anemia masih terjadi Kota Yogyakarta dan Sleman. Tahun 2015, wilayah Kota Yogyakarta merupakan wilayah tertinggi kejadian ibu hamil yang mengalami anemia yaitu sebesar 32,29\% mengalami peningkatan $4,29 \%$ dari tahun sebelumnya (DIY, 2016).

Salah satu upaya penncegahan Anemia pada ibu hamil adalah dengan pemberian $\mathrm{Fe}$. Harapannya dengan adanya peningkatan cakupan pemberian Fe pada ibu hamil maka akan dapat menurunkan kejadian anemia pada ibu hamil yang kadang menjadi penyebab perdarahan saat persalinan ibu hamil tersebut dan berujung pada kematian ibu bersalin. Output dari pemberian tablet $\mathrm{Fe}$ pada ibu hamil adalah penurunan kejadian anemia pada ibu hamil, namun demikian fakta lain menunjukkan bahwa Puskesmas Wirobrajan memiliki cakupan pemberian $\mathrm{Fe}$ terendah diantara Puskesmas di wilayah Kota Yogyakarta yaitu F1(30 tablet) sebesar 47,89\% dan Fe3(90 tablet) sebesar 59,94\%, jauh di bawah target Dinas Kesehatan Kota Yogyakarta yang ditetapkan yaitu $90 \%$.

Hasil penelitian sebelumnya menunjukkan bahwa 50\% ibu belum memiliki pengetahuan yang baik mengenai anemia dan $64,3 \%$ diantaranya menderita anemia (Purbadewi \& Ulvie, 2013). Salah satu pengetahuan yang mendasar adalah tentang gizi yang dapat mempengaruhi pola makan dalam rangka pencegahan anemia pada ibu hamil. Maka perlu dilakukan analisis pola makan yang dapat mempengaruhi kejadian anemia.

\section{METODE PENELITIAN}

Penelitian ini merupakan penelitian non-eksperiment dengan metode deskriptif analitik menggunakan rancangan cross sectional. Populasi dalam penelitian ini adalah seluruh ibu hamil di wilayah Kota Yogyakarta sebanyak 86 orang. Teknik sampling dalam penelitian ini menggunakan purposive sampling dan mendapatkan jumlah responden sebanyak 76 responden.

Variabel bebas dalam penelitian ini adalah pola makan ibu hamil, sedangkan variabel terikat adalah kejadian anemia. Jenis data yang dikumpulkan adalah data primer dan data sekunder sebagai data penunjang. Data primer diperoleh dengan wawancara menggunakan kuesioner kepada ibu. Data kejadian anemia diperoleh dengan pengukuran kadar hemoglobin dengan menggunakan alat easy one touch. Analisis data bivariat untuk melihat hubungan variabel bebas dan terikat menggunakan uji Chi-Square atau Fisher Exact Test apabila syarat untuk uji Chi-Square tidak terpenuhi dengan tingkat kepercayaan $95 \%(\alpha=0,05 \%)$.

\section{HASIL DAN PEMBAHASAN}

Pengumpulan data dalam penelitian ini dilakukan dengan cara penyebaran kuesioner menggunakan Food Frequency Questionnaire (FFQ) dilanjutkan dengan pengukuran Hemoglobin $(\mathrm{Hb})$ dan wawancara mendalam. Karakteristik responden dalam penelitian ini meliputi usia responden, usia kehamilan, tingkat pendidikan, jumlah kehamilan, dan jarak kehamilan. Berdasarkan Tabel 1 menunjukkan bahwa responden sebagian besar berusia 21-30 (40,8\%) tahun dengan rata-rata umur 29,3 tahun. Tingkat pendidikan terbanyak adalah pendidikan menengah sebanyak 37 responden $(48,7 \%)$. Sebagian besar responden memasuki usia kehamilan trimester 2 sebanyak 31 responden $(40,8 \%)$ yang termasuk dalam kategori multigravida sebanyak 45 responden $(59,3 \%)$. Sebagian besar responden patuh dalam minum tablet $\mathrm{Fe}$ sebanyak 51 responden $(67,1 \%)$. 
Tabel 1 Distribusi Frekuensi Karakteristik Responden

\begin{tabular}{|c|c|c|}
\hline Karakteristik Responden & $\mathrm{f}$ & $\%$ \\
\hline \multicolumn{3}{|l|}{ Usia Responden (Tahun) } \\
\hline $17-20$ & 5 & 6,58 \\
\hline $21-30$ & 41 & 53,95 \\
\hline $31-40$ & 28 & 36,84 \\
\hline $41-50$ & 2 & 2,63 \\
\hline \multicolumn{3}{|l|}{ Tingkat pendidikan } \\
\hline Pendidikan Dasar & 15 & 19,7 \\
\hline Pendidikan Menengah & 37 & 48,7 \\
\hline Pendidikan Tinggi & 24 & 31,6 \\
\hline \multicolumn{3}{|l|}{ Usia Kehamilan (Bulan) } \\
\hline Trimester I ( $0-3$ bulan $)$ & 20 & 26,3 \\
\hline Trimester 2 ( $4-6$ bulan) & 31 & 40,8 \\
\hline Trimester 3 ( $7-9$ bulan) & 25 & 32,9 \\
\hline \multicolumn{3}{|l|}{ Status Paritas } \\
\hline Primigravida & 31 & 40,8 \\
\hline Multigravida & 45 & 59,3 \\
\hline \multicolumn{3}{|l|}{ Kepatuhan minum tablet Fe } \\
\hline Tidak & 25 & 32,9 \\
\hline Ya & 51 & 67,1 \\
\hline Total & 76 & 100 \\
\hline
\end{tabular}

Umur mempengaruhi daya tangkap dan pola pikir seseorang. Semakin bertambah umur akan semakin berkembang pula daya tangkap dan pola pikirnya, sehingga pengetahuan yang diperoleh semakin banyak. Pada ibu hamil, tidak hanya pengetahuan yang dibutuhkan dalam menjalani kehamilan, tetapi batasan usia pun akan mempengaruhi resiko yang dihadapi selama kehamilan.

Pada dasarnya usia ibu hamil dapat mempengaruhi anemia jika usia relatif muda (<20 tahun), karena pada umur tersebut masih terjadi pertumbuhan yang membutuhkan zat gizi lebih banyak, bila zat gizi yang dibutuhkan tidak terpenuhi, akan terjadi kompetisi zat gizi antara ibu dan bayinya. Pada penelitian ini ibu hamil anemia banyak yang berada pada usia 21-30 tahun sebanyak 37 responden $(53,95 \%)$, hal tersebut dikarenakan ada faktor lain yang mempengaruhi anemia selain usia ibu hamil. Penelitian ini sejalan dengan penelitian yang dilakukan oleh, bahwa sebesar $(52,6 \%)$ responden pada kelompok kasus memiliki usia yang berisiko terkena anemia. Pada ibu hamil yang menderita anemia dapat meningkatkan morbiditas maupun mortalitas ibu dan bayi, kemungkinan melahirkan bayi
BBLR dan prematur juga lebih besar. Anak yang dikandung oleh ibu yang menderita anemia juga akan mengalami penurunan kecerdasan inteljensia setelah dilahirkan (Parulian et al., 2016).

Hasil penelitian yang dilakukan oleh (Astriana, 2017), didapatkan p-value 0,018 menunjukkan ada hubungan yang bermakna antara umur dengan kejadian anemia pada ibu hamil. Hasil penelitian ini juga sejalan dengan (Salmariantity, 2012), menunjukkan hubungan umur dengan kejadian anemia pada ibu hamil dengan nilai uji statistik terbukti signifikan $p$ value $=0,012<0,005$ dengan nilai Prevalance Ratio $=1,8$ dan 96\% CI antara 1,07 - 3,28 yang artinya ibu hamil pada umur beresiko (< 20 tahun) berpeluang mendapatkan anemia 1,8 kali dibandingkan dengan ibu hamil pada umur tidak beresiko (20-35 Tahun).

Tingkat pendidikan ibu hamil dapat menyebabkan keterbatasan dalam upaya menangani masalah gizi dan kesehatannya. Pengetahuan gizi dan kesehatan akan berpengaruh terhadap pola konsumsi pangan. Semakin tinggi pendidikan tentang gizi dan kesehatan, maka semakin beragam pula jenis makanan yang dikonsumsi sehingga dapat memenuhi kecukupan gizi dan mempertahankan kesehatan individu.

Pada penelitian ini, tingkat pendidikan responden sebagian besar adalah pendidikan menengah sebanyak 37 responden $(48,7 \%)$. Tetapi masih terdapat responden yang berada pada tingkat pendidikan dasar sebanyak 15 responden (19,7 \%). Berdasarkan penelitian (Kefiyalew \& Eshetu, 2018), tingkat pendidikan berhubungan erat dengan kadar hemoglobin ibu hamil.

Tingkat pendidikan mempunyai hubungan dengan tingkat kesehatan. Semakin tinggi tingkat pendidikan, semakin mudah menerima konsep hidup sehat secara mandiri, kreatif, dan berkesinambungan. Tingkat pendidikan itu sangat mempengaruhi kemampuan penerimaan informasi gizi. Tingkat pendidikan ikut menentukan atau mempengaruhi mudah tidaknya seseorang menerima suatu pengetahuan, semakin tinggi pendidikan maka seseorang akan lebih mudah menerima informasi gizi. Biasanya seorang ibu hamil yang berpendidikan tinggi dapat menyeimbangkan pola konsumsinya. Apabila pola konsumsinya sesuai maka asupan zat gizi yang diperoleh akan tercukupi, sehingga 
kemungkinan besar bisa terhindar dari masalah anemia. Rendahnya tingkat pendidikan ibu hamil dapat menyebabkan keterbatasan dalam upaya menangani maslah gizi dan kesehatan keluarga dan mempengaruhi penerimaan informasi sehingga pengetahuan tentang zat besi ( $\mathrm{Fe}$ ) menjadi terbatas dan berdampak pada terjadinya defisiensi zat besi (Purwaningtyas \& Prameswari, 2017).

Ibu hamil yang berada di wilayah Puskesmas Wirobrajan sebagian besar patuh dalam minum tablet Fe sebanyak 51 responden $(67,1 \%)$, sedangkan yang tidak patuh minum tablet Fe sebanyak 25 responden $(32,9 \%)$.

Hasil penelitian menunjukkan bahwa sebagian besar ibu hamil patuh mengkonsumsi tablet Fe. Hal tersebut dapat dipengaruhi oleh pendidikan ibu hamil yang baik sesuai hasil penelitian bahwa sebagian ibu hamil termasuk dalam kategori tingkat pendidikan menengah. Pengetahuan tersebut menghasilkan kesadaran bagi ibu hamil untuk mengkonsumsi tablet $\mathrm{Fe}$ secara teratur selama kehamilannya. Adapun ibu yang patuh mengkonsumsi tablet Fe jumlahnya cukup banyak. Hal ini dapat dipengaruhi oleh efek samping yang kurang nyaman dirasakan oleh ibu ketika mengkonsumsi tablet Fe seperti, mual, muntah dan nyeri ulu hati (Arifin, 2008).

Suplemen oral zat besi dapat menyebabkan mual, muntah, kram lambung, nyeri ulu hati, dan konstipasi. Tetapi derajat mual yang ditimbulkan oleh setiap preparat tergantung pada jumlah elemen zat besi yang diserap. Takaran zat besi di atas 60 mg dapat menimbulkan efek samping yang tidak bisa diterima oleh ibu hamil sehingga terjadi ketidakpatuhan dalam mengkonsumsi tablet Fe. Ibu hamil sangat penting mengkonsumsi tablet Fe selama kehamilan, karena kebutuhan zat besi ibu hamil meningkat selama kehamilan. Tablet $\mathrm{Fe}$ adalah garam besi dalam bentuk tablet/ kapsul yang apabila dikonsumsi secara teratur dapat meningkatkan jumlah sel darah merah. Wanita hamil mengalami pengenceran sel darah merah sehingga memerlukan tambahan zat besi untuk meningkatkan jumlah sel darah merah janin (Rasmaliah, 2004). Pemberian tablet besi dengan dosis satu tablet sehari dapat meningkatkan kadar $\mathrm{Hb}$ sebesar 53,65\% serta menunjukkan keluhan efek samping yang ringan. Semakin patuh ibu hamil mengkonsumsi tablet fe semakin kecil kemungkinan mengalami anemia dalam kehamilannya (P. H. Putri et al., 2015).

Hasil penelitian menunjukkan bahwa sebagian besar ibu hamil memasuki usia kehamilan trimester 2 sebanyak 31 responden $(40,8 \%)$. Ibu hamil yang memasuki trimester 1 sebanyak 20 responden $(26,3 \%)$ dan trimester 3 sebanyak 25 responden (32,9\%). Semakin bertambah usia kehamilan, maka akan semakin berisiko mengalami anemia. Hemodilusi atau pengenceran darah selama kehamilan akan mencapai maksimal 5-8 bulan, faktor hemodilusi ini dapat menyebabkan kadar hemoglobin darah ibu menurun hingga mencapai $10 \mathrm{gr} / \mathrm{dl}$. Oleh sebab itu, semakin meningkatnya usia kehamilan ibu maka resiko untuk menderita anemia menjadi semakin besar apabila tidak diimbangi dengan pola makan yang seimbang dan konsumsi Fe secara teratur.

Pada penelitian ini didapatkan hasil bahwa sebagian besar responden termasuk dalam status paritas multigravida sebanyak 45 $(59,3 \%)$, sedangkan primigravida sebanyak 31 responden $(40,8 \%)$. Status kehamilan dapat mempengaruhi derajat anemia, semakin sering seorang ibu melahirkan maka semakin besar resiko kehilangan darah dan berdampak pada penurunan kadar $\mathrm{Hb}$ (Tristiyanti, 2006). Penelitian yang dilakukan oleh Ramadani, dkk (2012) lebih dari separuh respondennya $(62,7 \%)$ ibu mempunyai paritas $\geq 3$. Sebanyak $46,3 \%$ ibu memiliki 4 orang anak, 20,9\% memiliki 5 orang anak. Hal ini menggambarkan bahwa masih banyak ibu di wilayah kerja puskesmas Seberang Padang dengan paritas kategori tinggi. Seorang ibu yang sering melahirkan mempunyai resiko mengalami anemia pada kehamilan berikutnya apabila tidak memperhatikan kebutuhan nutrisi karena selama hamil zat-zat gizi akan terbagi untuk ibu dan janin yang dikandungnya.

\section{Pola Makan Ibu Hamil}

Berdasarkan hasil pengisian kusioner tentang pola makan ibu hamil dengan menggunakan Food frequency Questionary dapat dilihat pada tabel 2 berikut.

Tabel 2

Distribusi Pola Makan Responden

Menurut Konsumsi Zat Enhancer dan zat Inhibitor

Konsumsi $\quad$\begin{tabular}{c} 
Pola Makan \\
\cline { 2 - 3 } Sering Jarang
\end{tabular}




\begin{tabular}{ccc} 
& $\mathrm{f}(\%)$ & $\mathrm{f}(\%)$ \\
\hline Zat enhancer & $49(64,5 \%)$ & $27(35,5 \%)$ \\
Zat inhibitor & $32(42,1 \%)$ & $44(57,9 \%)$ \\
\hline
\end{tabular}

Berdasarkan tabel 2 menunjukkan bahwa responden yang sering mengkonsumsi zat enhancer sebanyak 49 orang $(64,5 \%)$ dan yang jarang mengkonsumsi zat inhibitor sebanyak 44 orang $(57,9 \%)$.

Pola makan dan asupan gizi merupakan indikator penting dalam anemia ibu hamil (Kefiyalew \& Eshetu, 2018). Perilaku makan tergantung pada budaya dan lingkungan. Persepsi dan pandangan tabu pada beberapa makanan dapat mempengaruhi pola makan pada ibu hamil. Kebutuhan mikronurient ibu hamil meningkat dan penting untuk kesehatan ibu dan janin (Black, 2001). Defisiensi mikronutrient selama periode intrauterin berhubungan erat dengan morbiditas dan mortalitas bayi baru lahir (Kefiyalew \& Eshetu, 2018).

Pertumbuhan janin sangat tergantung pada hasil metabolisme tubuh yang ditransfer melalui plasenta untuk memenuhi kebutuhan ibu selama hamil dan nutrisi janin untuk tumbuh dan berkembang sehingga bayi yang dilahirkan dapat memiliki berat badan lahir normal Okubo et al. (2012). Hasil penelitian yang dilakukan di Banglades tahun 2013, asupan energi dan protein tidak berhubungan dengan berat lahir akan tetapi asupan lemak yang tinggi pada usia 18 minggu kehamilan berhubungan dengan berat lahir dan panjang badan serta ketebalan otot trisep. Berat badan lahir ini berhubungan dengan konsumsi susu, buah-buahan dan sayur sayuran hijau serta kekurangan asam folat berhubungan dengan berat lahir rendah (Rao et al., 2001).

Beberapa responden yang meski sering mengkonsumsi enhancher tetapi anemia, hal tersebut dapat disebabkan faktor lain, yaitu jarak kehamilan. Dari 9 ibu hamil yang anemia sebanyak 5 ibu hamil $(55,6 \%)$ yang mempunyai jarak kehamilan kurang dari 1 tahun. Meski separuh lebih responden patuh dalam mengkonsumsi tablet $\mathrm{Fe}$, ibu hamil yang mengalami anemia dapat disebabkan dalam mengkonsumsi tablet $\mathrm{Fe}$ tidak tepat waktunya. Apabila mengkonsumsi makanan dan minuman yang dapat menghambat penyerapan zat besi, sebaiknya dilakukan dua jam sebelum atau setelah mengkonsumsi tablet $\mathrm{Fe}$.
Berdasarkan hasil dari pengisian Food Frequency Questionare, menunjukkan konsumsi buah yang paling sering dikonsumsi ibu hamil yaitu pisang, pepaya, dan mangga. Sayuran yang paling sering dikonsumsi yaitu kembang kol, bayam, dan tauge. Sedangkan protein hewani yang sering dikonsumsi yaitu daging ayam.

Apabila pola makan ibu hamil dilihat dari frekuensi makan, sebagian besar mempunyai pola makan minimal 4 kali dalam sehari. Selain itu berdasarkan wawancara, tidak ada ibu hamil yang mengalami pica. Ibu hamil lebih jarang mengkonsumsi kopi daripada teh. Konsumsi teh dan kopi sebaiknya selama kehamilan dikurangi karena konsumsi kopi dan teh yang tinggi pada wanita hamil, terutama bagi mereka yang mengkonsumsinya tepat sebelum atau setelah makan, kemungkinan akan lebih lanjut mempengaruhi ketersediaan mineral seperti zat besi. Peningkatan konsumsi teh mengurangi penyerapan zat besi (Speedy, 2003).

\section{Kejadian Anemia Ibu Hamil}

Tabel 3

Distribusi Frekuensi Kejadian Anemia Ibu Hamil

\begin{tabular}{ccc}
\hline Kejadian Anemia & $\mathrm{f}$ & $\%$ \\
\hline Anemia & 9 & 11,8 \\
Tidak Anemia & 67 & 88,2 \\
\hline Total & 76 & 100,0 \\
\hline
\end{tabular}

Berdasarkan tabel 3 menunjukkan hasil bahwa sebagian besar ibu hamil yang berada di wilayah Puskesmas Wirobrajan tidak mengalami anemia sebanyak 67 responden $(88,2 \%)$, sedangkan yang mengalami anemia sebanyak 9 responden $(11,8 \%)$. Distribusi kejadian anemia berdasarkan umur kehamilan dapat dilihat pada tabel 4 berikut.

Tabel 4

Distribusi Kejadian Anemia Menurut Usia Kehamilan

\begin{tabular}{ccc}
\hline $\begin{array}{c}\text { Usia Kehamilan } \\
\text { (Trimester) }\end{array}$ & Jumlah & $\begin{array}{c}\text { Persentase } \\
(\%)\end{array}$ \\
\hline Trimester I $(0-3$ bulan) & 1 & 11 \\
Trimester $2(4-6$ bulan) & 5 & 55,5 \\
Trimester 3 $(7-9$ bulan) & 3 & 33,5 \\
\hline Total & 9 & 100 \\
\hline
\end{tabular}

Berdasarkan tabel 4 menunjukkan bahwa anemia paling banyak terjadi pada ibu 
hamil trimester 2 sebanyak 5 responden (55,5\%). Kadar $\mathrm{Hb}$ dalam penelitian ini menunjukkan hasil kadar $\mathrm{Hb}$ minimal 8,2 gr/dL dan maksimal 16,60 gr/dL. Secara keseluruhan responden mempunyai nilai kadar $\mathrm{Hb}$ rata-rata $12,19 \mathrm{gr} / \mathrm{dL}$ dengan standar deviasi $1,70 \mathrm{gr} / \mathrm{dL}$.

Ibu hamil dikatakan anemia ringan jika kadar $\mathrm{Hb}$ 9-10,9g\%, anemia sedang jika kadar $\mathrm{Hb} 7-8,9 \mathrm{~g} \%$ dan anemia berat jika kadar $\mathrm{Hb}$ kurang dari 7g\%. Sedangkan menurut usia kehamilan ibu hamil dikatakan anemia bila kadar $\mathrm{Hb}$ kurang dari $11 \mathrm{~g} \%$ pada trimester I dan III atau $\mathrm{Hb}$ kurang dari $10,5 \mathrm{~g} \%$ pada trimester II (Fadlun \& Feryanto, 2011). Anemia ibu berkontribusi pada pertumbuhan dan berat lahir dalam siklus antargenerasi. Dengan demikian, memastikan asupan makanan yang cukup selama kehamilan sangat penting (Kalaivani, 2009).

Hasil penelitian menunjukkan bahwa sebagian besar responden tidak anemia sebanyak 67 responden $(88,2 \%)$ setelah dilakukan pemeriksaan kadar hemoglobin. Tetapi masih terdapat ibu hamil yang anemia sebanyak 9 responden $(11,8 \%)$. Ibu hamil yang anemia paling banyak pada ibu hamil trimester II yaitu sebanyak 5 responden $(55,5 \%)$.

Prevalensi anemia wanita usia subur (kadar hemoglobin $<12 \mathrm{~g} / \mathrm{dl}$ ) pada penelitian yang dilakukan oleh Sukidjo dan Sanjaja (2016), sebesar 9,6\%. Pada WUS dengan status feritin yang kurang berisiko untuk menjadi anemia sebesar 4,01 kali (95\% CI: 1,03-15,48) dibandingkan dengan WUS dengan status feritin yang cukup setelah dikontrol oleh variabel status vitamin A dan umur. Penelitian (Buseri et al., n.d.) di Nigeria mendapatkan angka prevalensi anemia pada WUS yang tidak hamil sebesar 16,7 persen, dan pada WUS yang hamil sebesar 23,2 persen. Penelitian Pala dan Dundar (2008), di Turki mendapatkan angka prevalensi anemia WUS sebesar 32,8 persen. Sedangkan di Etiopia menurut Ethiopian Demographic and Health Survey (EDHS, 2011) prevalensi anemia pada WUS menyusui adalah $29,9 \%$ pada tahun 2005 dan 18,5\% pada tahun 2011. Persentase anemia diantara WUS yang hamil sebesar $30,6 \%$ pada tahun 2005 dan $22 \%$ pada tahun 2011. Selanjutnya persentase anemia pada WUS yang tidak hamil atau menyusui sebesar $23,9 \%$ pada tahun 2005 dan $15 \%$ pada tahun 2011.

Faktor utama yang dapat menyebabkan anemia kehamilan adalah kurangnya konsumsi tablet besi (Manuaba, 2004). Pada ibu hamil konsumsi tablet besi dianjurkan minimal 1 kali sehari. Dalam penelitian ini sebagian besar responden patuh dalam konsumsi tablet Fe $(67,1 \%)$.

Selain itu, pendidikan juga menjadi faktor pendukung terjadinya anemia, dimana sebagian besar ibu hamil $(48,7 \%)$ adalah berpendidikan menengah. Hasil penelitian ini sejalan dengan penelitian yang dilakukan oleh Yanti \& Sulistianingsih (2016) yang memiliki pendidikan tinggi dan mengalami anemia kehamilan sebanyak 80 orang $(60,2 \%)$ sedangkan yang memiliki pendidikan rendah dan mengalami anemia kehamilan sebanyak 28 orang $(80 \%)$.

\section{Pola Makan dan Kejadian Anemia Pada Ibu Hamil}

Untuk mengetahui hubungan pola makan dengan kejadian anemia, maka dilakukan analisis uji statistik chi square. Hasil dapat dilihat pada tabel 5 dan 6 sebagai berikut.

Tabel 5

Analisis Pola Makan berdasarkan konsumsi Zat Enhacer dengan kejadian anemia

\begin{tabular}{|c|c|c|c|c|c|c|c|}
\hline \multirow{3}{*}{$\begin{array}{l}\text { Pola Makan } \\
\text { berdasarkan } \\
\text { Konsumsi Zat } \\
\text { Enhancer }\end{array}$} & \multicolumn{4}{|c|}{ Kejadian Anemia } & \multicolumn{2}{|c|}{ Total } & \multirow{2}{*}{$\begin{array}{c}\mathrm{p} \\
\text { value }\end{array}$} \\
\hline & \multicolumn{2}{|c|}{ Anemia } & \multicolumn{2}{|c|}{$\begin{array}{c}\text { Tidak } \\
\text { anemia }\end{array}$} & & & \\
\hline & $\mathrm{n}$ & $\%$ & $\mathrm{n}$ & $\%$ & $\mathrm{n}$ & $\%$ & \\
\hline Jarang & 2 & 22,2 & 25 & 37,3 & 27 & 35,5 & \\
\hline Sering & 7 & 77,8 & 42 & 62,7 & 49 & 64,5 & 0,478 \\
\hline Total & 9 & 100,0 & 67 & 100,0 & 76 & 100,0 & \\
\hline
\end{tabular}

Berdasarkan hasil uji statistik chi square pada tabel 5, menunjukkan konsumsi zat enhancer dengan kejadian anemia didapatkan nilai $p$-value $=0,478 \quad(>0,05)$ yang artinya bahwa konsumsi zat enhancer tidak berhubungan dengan kejadian anemia.

Tabel 6

Analisis Pola Makan berdasarkan Konsumsi Zat Inhibitor dengan kejadian anemia

\begin{tabular}{|c|c|c|c|c|c|c|c|}
\hline \multirow{3}{*}{$\begin{array}{c}\text { Pola Makan } \\
\text { berdasarkan } \\
\text { Konsumsi Zat } \\
\text { Inhibitor }\end{array}$} & \multicolumn{4}{|c|}{ Kejadian Anemia } & \multicolumn{2}{|c|}{ Total } & \multirow{3}{*}{$\begin{array}{c}\mathrm{p} \\
\text { value }\end{array}$} \\
\hline & \multicolumn{2}{|c|}{ Anemia } & \multicolumn{2}{|c|}{$\begin{array}{c}\text { Tidak } \\
\text { anemia }\end{array}$} & & & \\
\hline & $\mathrm{n}$ & $\%$ & $\mathrm{n}$ & $\%$ & $\mathrm{n}$ & $\%$ & \\
\hline Sering & 4 & 44,4 & 28 & 41,8 & 32 & 42,1 & \\
\hline Jarang & 5 & 55,6 & 39 & 58,2 & 44 & 57,9 & 1,000 \\
\hline Total & 9 & 100,0 & 67 & 100,0 & 76 & 100,0 & \\
\hline
\end{tabular}


Berdasarkan hasil uji statistik chi square pada tabel 6, menunjukkan konsumsi zat inhibitor dengan kejadian anemia didapatkan nilai $p$-value $=1,000 \quad(>0,05)$ yang artinya bahwa konsumsi zat inhibitor tidak berhubungan dengan kejadian anemia.

Berdasarkan hasil penelitian menunjukkan bahwa responden yang sering mengkonsumsi zat enhancer dan tidak mengalami anemia sebanyak 42 responden $(62,7 \%)$, sedangkan responden yang jarang mengkonsumsi inhibitor dan tidak mengalami anemia sebanyak 39 responden $(58,2 \%)$. Meskipun masih ada yang sering mengkonsumsi enhancer dan mengalami anemia sebanyak 7 responden $(77,8 \%)$ dan yang sering mengkonsumsi inhibitor tetapi tidak anemia sebanyak 28 responden $(41,8 \%)$. Berdasarkan penelitian Kefiyalew (2018), konsumsi teh dan kopi merupakan prediktor penting dalam kadar hemoglobin ibu hamil. Pola konsumsi sumber penghambat penyerapan zat besi (Inhibitor) berpengaruh terhadap status anemia. Makan yang merupakan sumber penghambat penyerapan zat besi (Inhibitor) yaitu tanin dan oksalat yang banyak terkandung dalam makanan seperti kacang-kacangan, pisang, bayam, coklat, kopi, dan teh (Masthalina, 2015). Penelitian Putri dan Sumarmi pada pengantin wanita (19-29 tahun) di Kabupaten Probolinggo juga menunjukkan bahwa konsumsi zat besi sebagian besar adalah nonheme dan kurang makanan sumber zink (S. I. Putri \& Sumarmi, 2013).

Berdasarkan penelitian Gozali (2018), terdapat hubungan yang bermakna antara pola makan dengan kejadian anemia $(\mathrm{p}<0,05)$, dengan interpretasi semakin kurang pola makan ibu hamil maka kejadian anemia semakin tinggi. Ibu hamil diharapkan memiliki pola makan yang baik sesuai jumlah kebutuhan pada pada masa kehamilan. Hasil penelitian ini juga didukung oleh Pertiwi, (2013), dengan judul hubungan antara pola makan dengan kejadian anemia pada ibu hamil di Wilayah Kerja Puskesmas Kerjo Kabupaten Karanganyar, dengan hasil penelitian $49 \%$ ibu hamil memiliki kebiasaan makan utama < 3 kali sehari, 16,3\% ibu hamil mengkonsumsi kurang dari 5 jenis makanan sehari, 36,7 ibu hamil mengalami anemia dan 63,3\% tidak ada anemia. Ada hubungan antara frekuensi makan dengan kejadian anemia $(p=0,002)$ ada hubungan antara jenis makanan dengan kejadian anemia $(\mathrm{p}=0,01)$ dan disimpulkan hasil penelitian terdapat hubungan pola makan dengan kejadian anemia ibu hamil.

Menurut WHO perlu adanya intervensi peningkatan sumber zat besi yang bioavailabilitas tinggi dalam makanan wanita usia reproduksi. Selain itu perlu adanya diversifikasi makanan, suplementasi zat besi, dan fortifikasi yang universal untuk menurunkan tingkat anemia. Menurut Black et al. (2013) bahwa meningkatkan status zat besi pada masa pra konsepsi sama seperti pemberian suplemen mikronutrient besi folat selama kehamilan yang akan menurunkan kejadian berat bayi lahir rendah (BBLR). Penelitian Taha et al. (2014) menyimpulkan bahwa status zat besi pada janin dan status zat besi bayi yang baru lahir tergantung pada status besi pada ibu hamil dan oleh karena itu, kekurangan zat besi pada ibu berarti bahwa janin yang tumbuh mungkin akan kekurangan zat besi juga.

\section{KESIMPULAN}

1. Pola makan responden berdasarkan yang sering konsumsi zat enhancer sebanyak 49 orang $(64,5 \%)$ dan yang jarang mengkonsumsi zat inhibitor sebanyak 44 orang $(57,9 \%)$.

2. Sebagian besar responden tidak mengalami anemia sebanyak 67 responden $(88,2 \%)$

3. Tidak ada hubungan yang signifikan secara statistik antara pola makan berdasarkan konsumsi zat enhancer dan kejadian anemia dengan nilai $\mathrm{p}$ value $=0,478$

4. Tidak ada hubungan yang signifikan secara statistik antara pola makan berdasarkan konsumsi zat inhibitor dan kejadian anemia dengan nilai $\mathrm{p}$ value $=1,000$

5. Berdasarkan hasil penelitian, maka perlu meningkatkan program edukasi pola makan pada ibu hamil dengan program kelompok pendamping ibu hamil.

\section{REFERENSI}

Adriani M., Bambang W., 2014. Peranan Gizi dalam siklus kehidupan. Jakarta , Kencana Prenadamedia Grup. 
Almatsier, S. 2003. Prinsip Dasar Ilmu Gizi. Jakarta: Gramedia Press

Arifin, Y. (2008). Hubungan pemberian tablet zat besi dengan anemia pada ibu hamil di Klinik Deli Tua Tahun 2008. Terdapat Pada http://httpyasirblogspotcom. blogspot.com/2009/01/hubunganpemberiantablet-zat-besi. html. diakses, 24.

Astriana, W. (2017). Kejadian anemia pada ibu hamil ditinjau dari paritas dan usia. Aisyah: Jurnal Ilmu Kesehatan, 2(2), 217394

Black, R. E. (2001). Micronutrients in pregnancy. British Journal of Nutrition, 85(S2), S193-S197

Black, R. E., Victora, C. G., Walker, S. P., Bhutta, Z. A., Christian, P., De Onis, M., Ezzati, M., Grantham-McGregor, S., Katz, J., \& Martorell, R. (2013). Maternal and child undernutrition and overweight in low-income and middleincome countries. The Lancet, 382(9890), 427-451.

Buseri, F. I., Uko, E. K., Jerimiah, Z. A., \& Usanga, E. A. (n.d.). Prevalence and Risk Factors of Anaemia among Pregnant Women in Nigeria. The Open Haematology Journal. 2008; 2: 14-19.

Darnton-Hill, I., Paragas, N., \& CavalliSforza, T. (2007). Global perspectives: accelerating progress on preventing and controlling nutritional anemia. Nutritional Anemia, 359.

Fadlun, Feryanto. 2011. Asuhan Kebidanan Patalogis. Jakarta: Salemba Medika.

Gozali, W. (2018). Hubungan Pola Makan dengan Kejadian Anemia pada Ibu Hamil di Wilayah Kerja Puskesmas Buleleng III. International Journal of Natural Science and Engineering, 2(3), 117-122

Hill Ian D., Neal Paragas, Tommaso Cavalli S. 2007. Global perspective: accelerating progress on preventing and controling nutritional anemia. Sight and Life Pres
Jackson, A. A. (2007). Anemia in severe undernutrition (malnutrition). Nutritional Anemia, 215.

Kalaivani, K. (2009). Prevalence \& consequences of anaemia in pregnancy. Indian J Med Res, 130(5), 627-633

Kefiyalew, J., \& Eshetu, G. (2018). Assessment of dietary pattern and factors that affect hemoglobin concentration of third trimester pregnant women at Ambo governmental health institutions, Ethiopia. J Nutr Hum Health, 2, 36-42

Masthalina, H. (2015). Pola Konsumsi (faktor inhibitor dan enhancer fe) terhadap Status Anemia Remaja Putri. KEMAS: Jurnal Kesehatan Masyarakat, 11(1), 80-86.

McLean, E., Egli, I., Cogswell, M., Benoist, B. de, \& Wojdyla, D. (2007). Worldwide prevalence of anemia in preschool aged children, pregnant women and non-pregnant women of reproductive age. In Nutritional anemia (pp. 1-12). Sight and life Press

Melorys dan Galuh. 2017. Faktor Kejadian Anemia Pada Ibu Hamil. Higeia Journal Of Public Health Research and Development. UNNES. http://journal.unnes.ac.id/sju/index.php /higenia

Okubo, H., Miyake, Y., Sasaki, S., Tanaka, K., Murakami, K., Hirota, Y., \& Group, C. H. S. (2012). Maternal dietary patterns in pregnancy and fetal growth in Japan: the Osaka Maternal and Child Health Study. British Journal of Nutrition, 107(10), 15261533.

Pala K, Dundar N. 2008. Prevalence \& Risk Faktors of Anemia Among Women of Reproductive Age in Bursa, Turkey, Indian. Journal Medical Res 128.

Parulian, I., Roosleyn, T., Tinggi, S., Kesehatan, I., \& Widya, J. I. (2016). Strategi dalam penanggulangan pencegahan anemia pada kehamilan. Jurnal Ilmiah Widya, 3(3), 1-9. 
Pertiwi, A. S. (2013). Hubungan Antara Pola Makan Dengan Kejadian Anemia Pada Ibu Hamil Di Wilayah Kerja Puskesmas Kerjo Kabupaten Karanganyar. Universitas Muhammadiyah Surakarta

Purbadewi, L., \& Ulvie, Y. N. S. (2013). Hubungan Tingkat Pengetahuan Tentang Anemia Dengan Kejadian Anemia Pada Ibu Hamil. Jurnal Gizi, 2(1)

Purwaningtyas, M. L., \& Prameswari, G. N. (2017). Faktor kejadian anemia pada ibu hamil. HIGEIA (Journal of Public Health Research and Development), 1(3), 43-54.

Putri, P. H., Sulistiyono, A., \& Mahmudah, M. (2015). Analisis Faktor yang Mempengaruhi Anemia pada Kehamilan Usia Remaja. Majalah Obstetri \& Ginekologi, 23(1), 33-36

Putri, S. I., \& Sumarmi, S. (2013). Perbandingan konsumsi zat gizi, status gizi, dan kadar hemoglobin pengantin wanita di wilayah pantai dan pertanian kabupaten probolinggo. Media Gizi Indones, 9, 72-77.

Putri, Sulistyono, Mahmudah. 2015. Analisis Faktor yang Mempengaruhi Anemia pada Kehamilan Usia Remaja. Majalah Obstetri \& Ginekologi, volume 23 No. 1 Januari - April, 2015. Universitas Airlangga.

Rao, S., Yajnik, C. S., Kanade, A., Fall, C. H. D., Margetts, B. M., Jackson, A. A., Shier, R., Joshi, S., Rege, S., \& Lubree, H. (2001). Intake of micronutrient-rich foods in rural Indian mothers is associated with the size of their babies at birth: Pune Maternal Nutrition Study. The Journal of Nutrition, 131(4), 1217-1224.

Roosleyn. 2016. Strategi dalam Penanggulangan Pencegahan Anemia pada Kehamilan. Jurnal Ilmiah Widya, Volume 3 Nomor 3 januari-Juli 2016. STIKES Binawan.

Salmariantity. (2012). Faktor-Faktor Yang Berhubungan Dengan Anemia Pada Ibu Hamil Di Wilayah Kerja Puskesmas Gajah Mada Tembilahan Kabupaten Indragiri Hilir Tahun 2012. Who 2001, 114

Soetjiningsih. (2010). Tumbuh Kembang Remaja dan Permasalahanya. Jakarta: PT. Rhineka Cipta.

Speedy, A. W. (2003). Global production and consumption of animal source foods. The Journal of Nutrition, 133(11), 4048S-4053S.

Syari, Serudji, Mariarti. 2015. Peran Asupan Zat Gizi Makronutrien Ibu Hamil terhadap Berat Badan Lahir Bayi di Kota Padang. Jurnal Kesehatan Andalas. http://jurnal.fk.unand.ac.id.

Taha, A., Azhar, S., Lone, T., Murtaza, G., Khan, S. A., Mumtaz, A., Asad, M. H. H. Bin, Kousar, R., Karim, S., \& Tariq, I. (2014). Iron deficiency anaemia in reproductive age women attending obstetrics and gynecology outpatient of university health centre in Al-Ahsa, Saudi Arabia. African Journal of Traditional, Complementary and Alternative Medicines, 11(2), 339-342

Tristiyanti, W. F. (2006). Faktor-faktor yang mempengaruhi status anemia pada ibu hamil di Kecamatan Ciampea, Kabupaten Bogor, Jawa Barat. Skripsi. Fakultas Pertanian Institut Pertanian Bogor

Yanti, D. A. M., \& Sulistianingsih, A. (2016). Faktor-Faktor Terjadinya Anemia Pada Ibu Primigravida di Wilayah Kerja Puskesmas Pringsewu Lampung. Jurnal Keperawatan, 6(2). 